\title{
"De acordo com a moderna pedagogia": as lições, as coisas e a materialidade na Instrução Pública do Rio Grande do Sul (1891-1928) ${ }^{1}$
}

"According to the modern pedagogy": lessons, things and materiality in the Public Instruction of Rio Grande do Sul, Brazil (1891-1928)

"De acuerdo con la moderna pedagogía": las lecciones, las cosas y la materialidad en la Instrucción Pública de Rio Grande do Sul, Brasil (1891-1928)

\author{
Cristiane Indiara Vernes Miglioranza \\ Universidade Federal do Rio Grande do Sul (Brasil) \\ http://lattes.cnpq.br/4874493405756927 \\ https://orcid.org/0000-0002-8029-6678 \\ crismiglio@hotmail.com \\ Zita Rosane Possamai \\ Universidade Federal do Rio Grande do Sul (Brasil) \\ Bolsista de Produtividade em Pesquisa do CNPq \\ http://lattes.cnpq.br/4910388368160076 \\ https://orcid.org/0000-0003-4014-5389 \\ zitapossamai@gmail.com
}

\section{Resumo}

Este trabalho analisa o conteúdo dos relatos dos inspetores gerais da Instrução Pública do Rio Grande do Sul a partir das noções de cultura material escolar e de cultura visual escolar, cotejando-os com outros documentos e com bibliografia especializada. Aponta para a existência de uma preocupação, seguida de ação, em aparelhar e prover as escolas com as novidades do então embrionário mercado de produtos educativos, tendo em vista a modernização da escola primária. Destaca que os profissionais técnicos do Estado estavam atentos às ideias e às práticas utilizadas em outros países. Conclui que houve a criação de soluções econômicas e logísticas para a manutenção do fornecimento desse material, e distingue as coleções escolares do Museu Julio de Castilhos, o mobiliário fabricado nas oficinas da Casa de Correção e a adaptação e edição locais de livros didáticos.

Palavras-chave: Instrução Pública. Lição de Coisas. Cultura Material Escolar. Cultura Visual Escolar.

\footnotetext{
${ }^{1}$ Uma versão parcial desse trabalho foi publicada nos anais do I Seminário Nacional História e Patrimônio Cultural, (MIGLIORANZA; POSSAMAI, 2016). Este trabalho teve apoio do Conselho Nacional de Desenvolvimento Científico e Tecnológico (CNPq) e da Fundação Coordenação de Aperfeiçoamento de Pessoal de Nível Superior (CAPES).
} 


\begin{abstract}
This paper analyzes the content of the reports of the general inspectors of the Public Instruction in Rio Grande do Sul, Brazil, from the notions of material and visual school culture, comparing them with other documentary sources and with specialized bibliography. It points to the existence of a concern, followed by action in equipping and provide schools with the innovations of the embryonic educational products market, with views to "civilization" of the population in the positivist model. It notes that State technical professionals were attentive to the practices used in other countries. It concludes that economic and logistics solutions to maintain the supply of this material were created and distinguishes amongst them the school series from Julio de Castilhos Museum, the furniture manufactured in the workshops of the House of Correction and the local adaptation and edition of textbooks.
\end{abstract}

Key Words: Public Instruction. Lessons from Things. Material School Culture. Visual School Culture.

\title{
Resumen
}

Este trabajo analiza el contenido de los informes de los inspectores generales de la Instrucción Pública de Rio Grande do Sul, Brasil, desde las nociones de cultura material y de cultura visual de la escuela, comparándolos con otras fuentes documentales y bibliografía especializada. Se apunta a la existencia de una preocupación, seguida de acción, en equipar las escuelas con las novidads del entonces embrionario mercado de productos educativos, con miras a la "civilización" de la población en el modelo positivista. Se observa que los profesionales técnicos del Estado estaban atentos a las prácticas utilizadas en otros países. Se apunta para la creación de soluciones económicas y logísticas para mantener el abastecimiento de este material a las escuelas, con distinción para las colecciones escolares del Museo Julio de Castilhos, la mobília fabricada en los talleres de la Casa de Corrección y la adaptación y edición locales de libros didácticos.

Palabras Clave: Instrucción Pública. Lecciones de Cosas. Cultura Material de la Escuela. Cultura Visual de la Escuela. 
Ao abordar a cultura escolar como objeto histórico, Dominique Julia reforça a importância da análise a partir de um contexto mais amplo, do qual fazem parte as relações com outras culturas, sejam elas religiosas, sociopolíticas ou de socialização (JULIA, 2001). Desta forma, na cultura escolar estariam inseridas tanto as normas relativas aos conhecimentos a ensinar e condutas a inculcar, quanto as práticas para a transmissão de conhecimentos e incorporação de comportamentos conforme as épocas. Deste conceito mais amplo, derivou a noção de cultura material escolar (VIDAL, 2005; ALVES, 2010), que compreende um vasto repertório composto por artefatos, edificações, mobiliário, manuais e materiais didáticos. A esta última categoria agregamos, a noção de cultura visual escolar (POSSAMAI, 2015; KNAUSS, 2006), por esta apontar para a especificidade da visualidade no âmbito da escola e estar estreitamente vinculada à cultura material, tendo em vista que as imagens estiveram sempre atreladas aos artefatos que lhes deram configuração. A pesquisa da materialidade e da visualidade escolar, no entanto, não pode ser circunscrita apenas às propriedades intrínsecas dos artefatos e imagens ou naquilo que se convencionou chamar de "história dos objetos" (MENESES, 1992). Como ressaltam vários estudos (ALVES, 2010; VIDAL, FARIA, 2005; SOUZA, 2007), as coisas materiais e visuais são fruto do trabalho humano, oriundo de relações sociais; vinculam-se às práticas escolares e comportam representações sobre diversos aspectos da cultura escolar.

Partindo destas concepções, as noções de cultura material escolar e cultura visual escolar permitem circunscrever universos específicos relacionados a uma variedade de artefatos e imagens que tomaram parte na vida dos sujeitos em seus momentos de formação. Neste sentido, o trabalho de pesquisadores como Antonio Viñao (2010), Augustín Escolano Benito (2010), Elomar Tambara e Eduardo Arriada (2012), Margarida Felgueiras (2005), Paulo Knauss (2006), Ulpiano Bezerra de Meneses (2005) e Zita Possamai (2009, 2012, 2014, 2015), entre muitos outros, oferece relevantes contribuições para o entendimento da história da educação a partir dessas perspectivas. Entretanto, nem sempre é possível dispormos dos elementos materiais e visuais produzidos pela cultura escolar ao longo do tempo e adequadamente preservados como patrimônio educativo. Mesmo os acervos guardados em instituições educacionais, pouco nos dizem quando dissociados de seu contexto de produção, circulação e das práticas que lhes deram utilidade e significação. Inserir esses objetos em uma dimensão visual presente no todo social (MENESES, 2005) é uma alternativa na busca por uma interpretação histórica mais enriquecedora. Neste sentido, se faz importante um olhar que transcenda o que está visível e que seja apto a identificar também as invisibilidades e o que elas têm a dizer. Nessa perspectiva, a busca por pistas, indícios e rastros impõe-se como metodologia para enfrentar documentos escritos e visuais à disposição das pesquisadoras, cuja produção projetava uma "escola desejada" (POSSAMAI, 2015), construída em palavras e imagens, conforme os ideais de progresso social, científico e econômico do positivismo gaúcho.

Dadas essas premissas, este trabalho analisa o ensino público no Rio Grande do Sul durante a Primeira República e suas imbricações com a denominada "moderna pedagogia"2 a partir das inovações materiais ocorridas nas escolas gaúchas entre o final do século XIX e as primeiras décadas do século XX. Transformações diretamente ligadas à adoção de um novo método de ensino, o intuitivo ${ }^{3}$, que por meio da estratégia "lição de coisas" proporcionou um salto não apenas metodológico, mas, também, tecnológico em se tratando do material usado em sala de aula e do mobiliário escolar, que passou a seguir padrões sanitários internacionais.

\footnotetext{
${ }^{2}$ Na reconfiguração do ensino público no Rio Grande do Sul pelo governo da Província após a Proclamação da República, a escolha reiteradamente declarada nos planejamentos da Instrução Pública pela "moderna pedagogia" é identificada com o método intuitivo, nos moldes de iniciativas em curso em São Paulo e em países como França, Estados Unidos, Alemanha, Argentina e Uruguai. Sobre o método intuitivo, ver Valdemarin (2004).

${ }^{3}$ O método intuitivo, sua estratégia de ensino - a lição de coisas -, a Instrução Pública do Rio Grande do Sul e sua relação com o Museu Júlio de Castilhos foram abordados anteriormente por Possamai (2012, 2014) em trabalhos que foram ponto de partida para este artigo.
} 
A perspectiva aqui apresentada é fruto de pesquisa nos relatórios da Secretaria de Estado dos Negócios do Interior e do Exterior entre os anos de 1891 a 1928, localizados no acervo do Memorial do Legislativo do Rio Grande do Sul. Nesses documentos estão contidos os relatos dos inspetores gerais da Instrução Pública ${ }^{4}$ João Abbot (1891-1894), Manoel Pacheco Prates (1894-1911) e Fernando Gama (1911-1928), bem como as impressões dos secretários José de Almeida Martins Costa Junior (1891-1892), Possidonio M. da Cunha Junior (1892-1894), João Abbot (1894-1904), José Barboza Gonçalves (1904-1905) e Protasio Alves (1906-1928). A metodologia empregada inclui a apreciação crítica do conteúdo dos relatórios, seu cotejamento com outros documentos (leis, decretos e catálogos de produtos) e também com bibliografia especializada, contendo o contexto histórico e social da época em vários estados brasileiros e também em diversos países. Assim, foi possível observar que práticas relacionadas à produção da cultura material escolar pela instrução pública do Rio Grande do Sul apontam circulações e transferências de ideias, saberes e artefatos entre o Brasil e outros países, vindo a enriquecer as perspectivas transnacionais da história da educação (PATEL, 2015; MATASCI, 2016; DITRICH, 2013).

\section{A "modernidade pedagógica" e a chegada de novas coisas ao Rio Grande do Sul}

O primeiro levantamento pós-Império sobre o ensino público no Rio Grande do Sul integra as poucas páginas do Relatório da Secretaria dos Negócios do Interior de 1891 e apresenta o quadro encontrado pelo Partido Republicano Rio-grandense (PRR) quando da Proclamação da República. Em 15 de novembro de 1889, havia 685 aulas públicas, discriminadas em três graus - $1^{\circ}$ (632 aulas); $2^{\circ}$ (34 aulas); e $3^{\circ}$ (19 aulas) - com estimativa total de 15.120 matriculados. Essa distinção por graus muda em 9 de setembro de 1891, quando um ato do governo provincial anula os programas de $2^{\circ}$ e $3^{\circ}$ graus e as aulas acabam todas pertencendo ao $1^{\circ}$ grau $^{5}$.

O relatório de 1893 mostra as mudanças operadas na Instrução Pública a partir desse quadro inicial e durante um período de dois anos. Sob a direção de João Abbot e administração interina de J. P. Henrique Duplan, o número de aulas públicas providas aumenta para 747, em um total de 839 existentes. No mesmo período, a Escola Normal conta com 187 matriculados: 93 no Curso Preparatório, 37 no primeiro ano do Curso Normal, 39 no segundo ano e 18 no terceiro ano.

Em 1894, João Abbot passa a secretário de Estado dos Negócios do Interior e Exterior (1894-1904). Mas, antes disso, em 1893, ele projeta a divisão do território do Estado em três zonas escolares, sob responsabilidade de um corpo fiscal composto de nove membros, três em cada zona, "de modo a exercerem permanente fiscalização" ; com a classificação das aulas em quatro entrâncias. Cabia aos inspetores, muito mais do que o trabalho de suporte às escolas e aos professores, a responsabilidade de relatar à Inspetoria Geral da Instrução Pública qualquer irregularidade ou dissonância com os princípios positivistas ${ }^{7}$ aplicados ao projeto educacional. Como explicado por Berenice Corsetti (1998):

\footnotetext{
${ }^{4}$ Transformada em $3^{\text {a }}$ Diretoria da Repartição Central pelo Decreto no 1746 , de 25 de julho de 1911.

5 A Lei Provincial 14, de 1837, promulga o Regulamento de Instrução Pública da Província do Rio Grande do Sul. Este é modificado em 1842 e reformulado em 1855, levando, em 1857, à divisão do sistema de ensino em escolas primárias de primeiro e segundo grau. (TAMBARA; ARRIADA, 2012, p. 80-82).

${ }^{6}$ Conforme explicado por João Abbot na página 89 do Relatório da Instrução Pública de 1893. Ver RIO GRANDE DO SUL. Relatório apresentado ao Presidente do Rio Grande do Sul em 15 de setembro de 1893 pelo Secretário de Estado interino dos Negócios do Interior e Exterior, Possidonio M. da Cunha Junior. Porto Alegre: Officinas Typographicas d'A Federação, 1893.

${ }^{7}$ Em sua análise sobre as propostas educativas para as escolas públicas no período, o historiador Solon Viola destaca o papel do positivismo como fonte ideológica usada pelos governantes sulinos para "projetar o desenvolvimento econômico e a frequente inserção no projeto de modernização [e que] serviu, também, para
} 
Os dirigentes educacionais do Rio Grande criaram conselhos escolares, formados por chefes de famílias que tinham seus filhos nas escolas, os quais desempenharam, gratuitamente, diversas tarefas de fiscalização, atividade que era considerada "de relevante serviço público". Entre elas estava o acompanhamento do comportamento moral e civil dos professores, o exame da escrituração, matrícula, frequiência e disciplina escolar, o exame do alunos, para verificar seu adiantamento, bem como o atestado mensal do exercício dos professores, para que eles pudessem receber seus vencimentos, entre outros trabalhos. O sistema era complementado com as visitas dos inspetores escolares, cercando a escola de uma vigilância permanente, com economia significativa de recursos. Esse sistema, marcado igualmente pela centralização administrativa, foi sofrendo aperfeiçoamentos ao longo do período. Os conselhos escolares transformaram-se nas delegacias escolares, que mantinham os membros das comunidades desempenhando atividades não-remuneradas. Os inspetores escolares foram ganhando maior especialização técnica, que se constituiu na inovação estabelecida ao final do período. Esse serviço todo era coordenado pelo Diretor Geral da Instrução Pública, que reunia, no âmbito da Secretaria do Interior e Exterior, as informações que possibilitavam o mais amplo conhecimento e controle do setor educacional rio-grandense. (CORSETTI, 1998, p. 66).

Nesta perspectiva de controle, o Estado, desde os primeiros anos do Regime Republicano, se coloca como responsável pela seleção e pelo provimento do material necessário à realização das aulas públicas. Em 1893, o secretário Cunha Jr. apresenta uma listagem dos materiais fornecidos: "livros, papel, tinta e mais objetos necessários ao expediente do ensino nas escolas públicas, de acordo com a prorrogação do respectivo contrato celebrado com Rodolpho José Machado" (RIO GRANDE DO SUL, 1893, p. 11). Itens destinados a todas as escolas de Porto Alegre, Rio Grande, São José do Norte, Pelotas, Jaguarão, Santa Maria, Cachoeira, Rio Pardo, Santa Cruz e São João Batista de Camaquã.

A questão do material de ensino passa a ser motivo de maior atenção a partir de 1896, quando o novo inspetor geral da Instrução Pública, Manoel Pacheco Prates, sugere que o Estado substitua os livros utilizados nos primeiros anos escolares por mapas murais, uma medida considerada mais econômica e mais de acordo com o que denomina como "moderna pedagogia", relacionada com o método intuitivo e com a lição de coisas. A partir da lei que trata da reforma da Instrução Pública no Estado de São Paulo ${ }^{8}$, Prates redige seu primeiro projeto de reforma para a Instrução Pública gaúcha, prevendo a centralização da aquisição de mobiliário e material escolar na própria Inspetoria, atividade até então realizada pelo Tesouro do Estado.

\footnotetext{
estabelecer as diretrizes educacionais das escolas públicas. Projetos de educação e de modernidade que estavam atrelados, fundamentalmente, aos princípios de uma sociedade baseada em uma economia de progresso e em uma educação geradora de homens íntegros, disciplinados e úteis. A proposta educacional dos governantes riograndenses influenciados pelo positivismo assume princípios educacionais voltados para a formação da cidadania, a formação da moral regeneradora, do projeto de inserção social dos trabalhadores, e a formação cultural enciclopédica da população". (VIOLA, 1998, p. 183).

${ }^{8}$ SÃO PAULO. Lei n. 88, de 8 de setembro de 1892.
} 
O Decreto n. 89, de 2 de fevereiro de 1897, vem para reorganizar o ensino público primário do Rio Grande do Sul e determinar, conforme as instruções do programa do ensino primário elaborado por Prates", a adoção do "método intuitivo e prático" e de "todas as importantes conquistas da moderna pedagogia", com vistas à instituição de um "sistema uniforme de educação racionalmente aplicado". A redação do programa, inspirada em experiências levadas a cabo nos Estados Unidos e na Argentina, contou com o auxílio do professor José Theodoro de Souza Lobo ${ }^{10}$. Conforme o relato de Manoel Pacheco Prates:

Quanto à parte pedagógica, foram consagradas as mais importantes conquistas pela moderna pedagogia. Nas instruções guiei-me tanto quanto me foi possível pela legislação norte-americana, vantajosamente aplicada na República Argentina; tive o cuidado de fazer as profundas modificações exigidas pelo nosso meio e pela Constituição do Estado. (RIO GRANDE DO SUL, 1897, p. 404-407).

$\mathrm{Na}$ reforma, Prates retoma uma ideia já anunciada por ele no relatório de 1896: substituir os livros utilizados em sala de aula por mapas murais. Para isso, ele sugere que o Estado obtenha os direitos de edição e de reprodução dos mapas murais, da Cartilha Maternal e do Livro de Deveres dos Filhos do educador português João de Deus Ramos Nogueira ${ }^{11}$, por meio de negociação direta com sua viúva em Lisboa.

Em 1898 Prates solicita verba à Assembleia dos Representantes para a aquisição de globos geográficos, mapas, coleções de cadernos de desenho, coleções próprias para lições de coisas e sólidos geométricos, que seriam fornecidos somente às aulas cujos professores tivessem competência reconhecida ${ }^{12}$ para trabalhar com o método intuitivo. Ele cita que estão adotados e distribuídos pela Instrução Pública, entre outros livros, os compêndios de Lições de Coisas por Saffray $^{13}$, os quais ele contava substituir por quadros murais nos anos seguintes. Os quadros

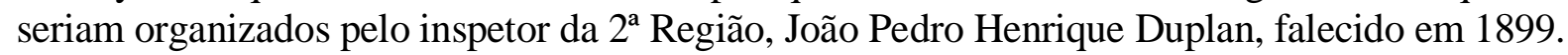

\footnotetext{
${ }^{9}$ RIO GRANDE DO SUL. Relatório apresentado ao Sr. Dr. Julio Prates de Castilhos, Presidente do Estado do Rio Grande do Sul, pelo Dr. João Abbot, Secretário de Estado dos Negócios do Interior e Exterior, em 30 de Julho de 1897. Porto Alegre: Officinas a Vapor da Livraria Americana, 1897.

${ }^{10}$ Engenheiro-geógrafo porto-alegrense formado pela Escola Central do Rio de Janeiro, ex-Escola Militar da Corte. Professor de português, francês e latim no Colégio Gomes; lecionou matemática elementar e superior na Escola Normal de Porto Alegre e publicou várias obras didáticas, entre as quais Geografia Elementar, Primeira Aritmética para Meninos e Segunda Aritmética para Meninos. (COSTA, 2011). Em 1877 fundou o Colégio Souza Lobo, pelo qual passaram personalidades como Júlio de Castilhos, Borges de Medeiros, Assis Brasil, Protasio Alves e Barros Cassal. A escola está localizada na Avenida Bahia, 948, Bairro São Geraldo, e hoje pertence à rede estadual de ensino.

${ }^{11}$ Medina (2012) ressalta que a importância dada à metodologia desenvolvida pelo poeta lírico português a partir da edição - muito popular - da Cartilha Maternal em 1876, a fez precursora de inúmeras publicações de caráter didático em Portugal e no Brasil. A autora destaca, inclusive, o Segundo Livro de Leitura, adaptação editada pela Livraria Selbach de Porto Alegre, de J.R. Fonseca e Cia., uma das empresas que figura entre as fornecedoras do Estado nos Relatórios da Instrução Pública. O livro atingiu, pelos menos, a 10a edição. O item analisado por ela, obtido em sebo, trazia 20 lições curtas e em letras grandes, não possuía exercícios, apresentava gravuras ilustrativas em branco e preto no início de cada texto e possuía capa em material cor de rosa, com uma bandeira do Brasil estampada entre o título e o nome da editora. (MEDINA, 2012, p.126).

12 Os planos apresentados por Prates para a instituição de um ensino público centralizado e com fins civilizatórios envolviam não apenas a instituição de uma pedagogia de ensino, mas também a qualificação de professores por meio de instituições do próprio Estado. Os profissionais poderiam ser incorporados ao sistema de ensino após sua formação, por meio de concurso público.

13 Lições de Coisas de Saffray foi um dos manuais que circularam no Brasil, quando da adoção do método intuitivo para o ensino. Conforme Valdemarin (2004), os manuais de lições de coisas foram publicados na Europa e nos Estados Unidos e, posteriormente, alguns foram traduzidos ao português. Entre esses manuais, foram estudados pela autora Lições de cousas, de Saffray; Plan d’Etudes et leçons de choses, de Jules Paroz; Exercises et travaux pour les enfants selon la methode et les procedés de Pestalozzi et de Froebel, de Fany Delon e M. Delon; Primeiras lições de Coisas de Norman Allison Calkins, traduzido por Rui Barbosa (Valdemarin, 2004).
} 
O relatório do ano seguinte (1899) traz a logística de distribuição do material de ensino às escolas: os professores enviavam seus pedidos aos inspetores regionais e estes, com base no conhecimento das necessidades das escolas que lhes era atribuído pelo governo, realizavam as modificações que julgavam convenientes. Então, era organizado um mapa geral com os nomes dos professores e o material necessário para cada escola. A partir dele, eram realizadas as remessas, cujo recibo deveria ser assinado pelo professor solicitante na fatura que acompanhava o fornecimento.

No relatório do inspetor geral datado de $1^{\circ}$ de junho de 1899 encontra-se uma listagem das obras e dos objetos recebidos pelo almoxarifado da Instrução Pública e distribuídos, até aquele ano, para as escolas. Os livros: Cartilha Samorim; Segundo Livro Samorim; Terceiro Livro de Leitura - Na terra, no mar e no espaço e Quarto Livro de Leitura - Pátria e dever, de Hilário Ribeiro; Seletas, de Alfredo Pinto; Cartilha João de Deus; Livro de Deveres dos Filhos, de João de Deus; Primeira e Segunda Aritmética, de Souza Lobo; Corografias, de Henrique Martins; geografias de Souza Lobo e de Henrique Martins; História do Brasil, de João von Frankenberg; História do Rio Grande do Sul, de João Maia; gramáticas de Bibiano de Almeida; Catequismos, do Dr. Lacerda; Cânticos Infantis; e Lições de Coisas, do Dr. Saffray. Os objetos: livros em branco de 50 folhas, resmas de papel pautado, resmas de papel liso, coleção de traslados ${ }^{14}$, canetas de madeira e de latão, lápis Faber, caixas de penas, tinteiros de vidro para as classes e para o professor, réguas métricas, tinta (litros), lápis de pedra, quadros de ardósia, caixas de giz, esponja (quilos), campainhas, talhas para água, canecas de ágata, cadernos de papel mata-borrão e urinóis em ágata e louça.

Mesmo contendo muitos itens considerados desatualizados por Prates, como é o caso de Lições de Coisas do Dr. Saffray, levou algum tempo para que o estoque do almoxarifado da Instrução Pública pudesse ser atualizado de acordo com a "moderna pedagogia" instituída como método de ensino pelo Decreto n. 89, de 1897. No ano de 1898, o inspetor geral solicita recursos à Assembleia dos Representantes para a aquisição do material para as lições de coisas, conforme já colocado anteriormente. Em 1900, ele explica ao secretário dos Negócios do Interior e do Exterior, João Abbot, o porquê da demora em convocar uma concorrência pública para a aquisição do material de ensino intuitivo: o preço elevado dos objetos, todos de fabricação estrangeira. Dois anos depois, Prates reitera a necessidade de mais verbas para a aquisição de livros e de materiais, como o mapa do Brasil de Levasseur e os mapas de figuras geométricas de Ezequiel Benigno de Vasconcellos Junior, reforçando o intuito de distribui-los às 903 escolas elementares existentes.

Em 1906, o médico e sanitarista Protasio Alves é empossado secretário estadual dos Negócios do Interior e Exterior. O decreto n. 874, de 28 de fevereiro daquele ano, elaborado a partir do trabalho de Prates, dá novo regulamento à Instrução Pública e suprime os Colégios Distritais, substituídos pelas Escolas Complementares, instituições com a dupla finalidade de ministrar o ensino complementar a todos que o desejassem e de preparar profissionais para o exercício do magistério.

Seguindo os planos traçados para a Instrução Pública, Alves informa ao governador Borges de Medeiros a encomenda, em 1907, de "aparelhos apropriados", entre eles, os "mapas murais para o ensino de leitura às classes elementares pelo método clássico João de Deus"15. Há, ainda, o início de uma movimentação para substituir o mobiliário das escolas,

${ }^{14}$ Nos relatórios apresentados pela Instrução Pública ao presidente do Estado do Rio Grande do Sul não consta detalhamento maior sobre este item. Infere-se, pela análise de pesquisas sobre a cultura material escolar da época no Brasil (BARBOSA, 2012; TAMBARA; ARRIADA, 2012), que se tratava de um conjunto de caixilhos gráficos móveis (fixados em mesa específica ou em suporte na parede) utilizados na alfabetização.

15 RIO GRANDE DO SUL. Relatório apresentado ao Sr. Dr. Antonio Augusto Borges de Medeiros, Presidente do Estado do Rio Grande do Sul, pelo Dr. Protasio Antonio Alves, Secretário de Estado dos Negócios do Interior e Exterior, em 15 de setembro de 1907. Porto Alegre: Typographia D’O Debate, 1907. p. 11. 
julgado em desacordo com as prescrições da ciência. Para isso, ele manda fabricar nas oficinas da Casa de Correção de Porto Alegre bancos e classes ${ }^{16}$ com várias alturas. Também encomenda duas mil carteiras, acompanhadas dos bancos, à empresa American Seating Company ${ }^{17}$, sediada nos Estados Unidos.

Em seu estudo sobre a cultura material e a aquisição da escrita no Brasil, Elomar Tambara e Eduardo Arriada (2012) traçam uma linha evolutiva do material utilizado para o ensino: desde os bancos de areia, passando pelas lousas de pedra até os cadernos pautados. Transformações que eram acompanhadas pelo mobiliário:

Assim, indicaram-se as carteiras individuais com tampo inclinado que facilitavam em "muito a regularidade dos traços e, portanto, a igualdade das letras". Sem constrangimento, os bancos e cadeiras fabricados em qualquer marcenaria no Brasil foram substituídos por móveis de ferro fundido importados dos Estados Unidos e Europa, em nome da modernidade do processo de ensino-aprendizagem. (TAMBARA; ARRIADA, 2012, p. 85).

Em seu relatório seguinte (1908), Protasio Alves, cujo trabalho em relação à Instrução Pública é muito mais ativo do que o de seu antecessor, afirma:

A higiene escolar tem melhorado. Desapareceu das escolas da Capital aquele anacrônico mobiliário, que foi substituído por elegantes carteiras adaptáveis à altura das crianças. Mandei cessar a distribuição de classes, como se fazia, de tamanho uniforme. (RIO GRANDE DO SUL, 1908, p. 10).

No ano de 1910, eram fornecidos pelas oficinas da Casa de Correção - que não estava conseguindo atender completamente os pedidos por conta da demanda - mesas, estrados, armários, classes (carteiras), bancos, cadeiras de braço, cadeiras simples, planos para cálculo, escudos, cabides. A lista ${ }^{18} \mathrm{com}$ as quantidades distribuídas e as cidades beneficiadas está na página 171 do Relatório da Instrução Pública apresentado por Manoel Pacheco Prates, que permanece como inspetor geral até 1911, quando assume a cátedra de Direito Civil na Academia de Direito de São Paulo (Editor, 1938). Ele é substituído na chefia da renomeada $3^{a}$ Diretoria da Repartição Central pelo funcionário de carreira Fernando de Albuquerque Gama, conforme o Decreto n. 1746, de 25 de julho de 1911.

Sob a administração de Protasio Alves, é encontrada uma alternativa mais viável aos cofres públicos para abastecer as escolas do que a importação: a (re)produção local a partir de modelos internacionais. Atividade que não ficou restrita apenas ao mobiliário e aos objetos, mas que se estendeu aos livros, entre eles os editados pela Livraria Selbach de Porto Alegre, como é o caso da Cartilha Maternal ou Arte de Leitura - Método João de Deus e do livro História do Brasil, de João von Frankenberg. As normas para edição de livros escolares e de leitura, entre elas as de linguagem, abordagem, impressão, material, acabamento e encadernação, estão contidas no relatório de 1913, páginas VI a VIII e preconizam, em linhas gerais, que "os livros

\footnotetext{
${ }^{16}$ Neste caso, se trata do móvel disponibilizado para os estudantes, também conhecido como carteira ou mesa.

${ }^{17}$ Empresa cujas atividades iniciaram em 1886 e que continuam até hoje. Seu primeiro produto foi a cadeiraescrivaninha escolar de ferro fundido e madeira de maple, combinação que revolucionou o mobiliário escolar. Site oficial: http://www.americanseating.com/

${ }^{18}$ Quadro das requisições de móveis feitas, por ofício, à Casa de Correção. In: RIO GRANDE DO SUL. Relatório apresentado ao Sr. Dr. Carlos Barbosa Gonçalves, Presidente do Estado do Rio Grande do Sul, pelo Dr. Protasio Antonio Alves, Secretário de Estado dos Negócios do Interior e Exterior, em 8 de setembro de 1910. Porto Alegre: Typrographia da Livraria Universal de Carlos Echenique, 1910. p. 171.
} 
escolares devem ser impressos em tinta preta, em bom papel, ligeiramente amarelo, não acetinado; serão de formato pouco volumoso, cosidos com fio de linha e não grampeados". Devem ser de fácil leitura e partir do "conhecido para o desconhecido", além disso:

De preferência devem os assuntos versar sobre os nossos homens e as nossas coisas. A nossa natureza, a geografia e história pátria, a vida e os feitos dos grandes benfeitores da humanidade; as descobertas e invenções mais importantes fornecerão o material para tais livros. (RIO GRANDE DO SUL, 1913, p. VII).

No período de 1911-1912, Protasio Alves organiza um "tombamento do mobiliário escolar do Estado" (RIO GRANDE DO SUL, 1912, p. IX), documento que estaria em posse de sua Secretaria, mas que não integra os relatórios pesquisados. No relato de 1912, ele registra a entrega de três mil carteiras duplas, "tipo Triumph"19, da American Seating Company, a 15 colégios elementares (Bagé, Canguçu, Arroio Grande, Santa Maria, Rio Pardo, Santa Cruz, Taquari, Bento Gonçalves, São Sebastião do Caí, São João de Camaquã, São Jerônimo, Encruzilhada, Passo Fundo, Caxias, São João do Montenegro) e a escolas urbanas de nove cidades (Rio Grande, Pelotas, Jaguarão, Santa Vitória do Palmar, Uruguaiana, Itaqui, Quaraí, São Borja, Santana do Livramento). A partir desse modelo, considerado revolucionário para a época, Alves envia ordem à Casa de Correção ${ }^{20}$ para a fabricação de similares que, em vez de madeira de maple e ferro fundido, são adaptadas à realidade local e produzidas com madeira nativa e ferro batido.

No relatório de 1912, o secretário ainda informa o fornecimento para a instrução especial de silvícolas de "além do habitual material escolar, sementes de cereais para servir à instrução agrária [...] e instrumentos para servir de atrativos por meio de agradável diversão, como gramofones com músicas e preleções adequadas". (RIO GRANDE DO SUL, 1912, p. VII). Em relação às novas aquisições para as escolas, avisa da chegada, juntamente com o mobiliário importado dos EUA, de globos para o estudo de cosmografia e de telas verdes para substituir os quadros negros. Com a remessa de material escolar comum, todas as instituições de ensino receberam cartas geográficas do Estado e do Brasil (edição Olavo Freire, ginasial, comprados por encomenda de Francisco Alves \& Cia. ${ }^{21}$ ). No ano seguinte (1913), elas são

19 As carteiras duplas importadas pelo Estado seguiam o modelo em que o assento trazia anexado em suas costas uma mesa para duas crianças. O móvel que serviu de inspiração para a American Seating Company para criação deste produto se chamava Triumph e pode ser visto no catálogo da empresa A. H. Andrews, de Chicago, disponibilizado pelo Smithsonian em http://americanhistory.si.edu/blog/2013/07/students-stay-in-your-seatsimproving-19th-century-school-desks.html.

20 As Oficinas da Casa de Correção de Porto Alegre integravam o complexo penitenciário construído, no século XIX, às margens do Guaíba, ao lado do Gasômetro. Conforme pesquisa de Tiago da Silva Cesar (2014), elas funcionavam desde o início das atividades da cadeia, em meados da década de 1850 . No princípio do trabalho na Cadeia Pública, os presos poderiam atuar em nove atividades: alfaiates, sapateiros, correeiros, carpinteiros, tamanqueiros, trançadores, tanoeiros, marceneiros e costureiras. O produto de seu trabalho abastecia o Arsenal de Guerra. No entanto, devido ao baixo número de apenados trabalhando - apenas 27,5\%, ou seja, 55 de 200 presos -, as oficinas foram fechadas em 1856 pelo Barão de Muritiba, então presidente da Província. Elas ressurgiram em 1896, com o então chefe de polícia do Estado, Borges de Medeiros. Nesse ano, novas oficinas foram criadas e outras melhoradas (SZCZPANIAK, 2005). Em 1888, achavam-se funcionando os trabalhos de sapataria, carpintaria, obras de carnaúba e identificação antropométrica, além de se aguardar para breve a oficina de tipografia. Em 1929, funcionavam ativamente as oficinas de serralheria, marcenaria, carpintaria, padaria, alfaiataria, sapataria, telas de arame e mosaicos.

${ }^{21}$ Livreiro Francisco Alves \& Cia., Rio de Janeiro. Companhia surgida na década de 1890 como Livraria Clássica de Alves \& Cia e considerada a principal editora de livros escolares do Brasil na época. (RAZZINI, 2004). 
beneficiadas com cartas geográficas das cinco grandes partes do mundo, editadas em português pela Casa Jablonski ${ }^{22}$, da França.

Durante a leitura dos relatórios, muitas são as referências às práticas utilizadas nos Estados Unidos, na Europa, na Argentina e no Uruguai (país ao qual foi enviada uma comitiva de professores gaúchos em $1913^{23}$ ), além da comparação entre a realidade regional com a de outros Estados, como São Paulo e Rio de Janeiro. Entre elas, a remodelação da instrução pública e do estudo da tradição nacional na Alemanha, citado por Manoel Pacheco Prates como modelo "unidade de direção do ensino" (RIO GRANDE DO SUL, 1897, p.403) e a adoção de métodos como o intuitivo e o sloyd, voltado às artes manuais e que, conforme explicação de Protasio Alves ao governador Borges de Medeiros:

O Sloyd transplantado para a América do Norte em 1888 pelo professor sueco Larrson, que veio contratado para ensiná-lo em Boston, tomou tal desenvolvimento, que excede hoje o que se faz no país de origem. As 'lições de coisas' fazem parte dos nossos programas de instrução; pois bem, as artes manuais são o seu complemento. (RIO GRANDE DO SUL, 1909, p. XI).

Percebe-se, assim, atenção às novidades pedagógicas em circulação nos demais estados brasileiros e em outros países, especialmente a partir da configuração de um mercado de produtos escolares para o projeto de educação pública. No impedimento da compra por parte da Instrução Pública, decorrência dos altos custos, foram buscadas alternativas de fabricação local, a exemplo de práticas correntes em outros países. Desse modo, entre 1911 e 1912 foi solicitada a montagem de mil coleções escolares, com 130 exemplares cada uma, pelo Museu Júlio de Castilhos (POSSAMAI, 2012, p. 10). Encarregado pelo inspetor geral Fernando Gama para coordenar a atividade, o diretor da instituição, Francisco Rodolfo Simch, confecciona museus escolares ${ }^{24}$ com:

[...] exemplares dos minerais mais comuns ao Estado, fragmentos de pedras, terra em frascos de vidro, com as discriminações próprias, a fim de serem distribuídos aos alunos de nossas escolas para que possam ter conhecimento rudimentar de mineralogia. (RIO GRANDE DO SUL, 1912, p. 230).

Essa produção "caseira" de museus escolares para lições de coisas não é uma solução inédita na história da educação. $\mathrm{Na}$ Argentina, cujas práticas inspiraram algumas das mudanças no ensino do Rio Grande do Sul, houve várias iniciativas empreendidas pela necessidade de se ter um material didático mais próximo à realidade local. É o caso dos projetos do italiano Pedro Scalabrini (1880-1900) e dos argentinos Guillermo Navarro (1895)

${ }^{22}$ Também conhecida como Livreiro Louis Jablonski, sediada em Paris. Jablonski e seu editor associado, Charles Vogt, publicavam várias obras pedagógicas, inclusive sobre o Brasil. Entre estas, a série "Ensaio de leitura para uso nas escolas da Amazônia", em três volumes, conforme o curso primário da época, escrita por Joaquim Freitas, e cuja 20ª edição saiu em 1898. (FIGUEIREDO, 2008, p. 34).

${ }_{23}$ Os relatórios completos dos membros da comitiva sobre suas visitas a escolas uruguaias e ao Museu e Biblioteca Pedagógicos do Uruguai constam no Relatório da $3^{\text {a }}$ Diretoria apresentado pelo diretor Fernando de A. Gama, em 30 de junho de 1914.

${ }^{24}$ Termo atribuído às coleções montadas pelo Museu Júlio de Castilhos, conforme definição de "museu escolar" como um termo polissêmico por Petry e Silva (2013), pois este variou de sentido conforme o contexto em que foi localizado. A partir de pesquisa sobre este tipo de iniciativa em Santa Catarina, as autoras identificaram seis aproximações para o termo: museu escolar, museu pedagógico, abrigo das coleções, museu em sala de aula, espaço físico especialmente destinado, e instituição dentro da escola. 
e Carlos M. Biedma (1908). Conforme pesquisa de Susana García (2014), o Museo Escolar Argentino, ou Museo Scalabrini, tinha o formato de caixas escolares com "entre 50 a 100 muestras de minerales, maderas, fósiles, moluscos, huesos y otros productos naturales del litoral del país, constituyendo cada objeto una lección de historia natural'(GARCÍA, 2014, p. 78). Já o Museo Escolar Nacional, de Navarro, era composto de um móvel de cedro com nove caixas grandes e cerca de mil amostras, seguindo o exemplo francês, e dava ênfase às indústrias nacionais e aos potenciais recursos produtivos. O Sistema Prático de Museus Escolares, de Biedma, era formado por 35 modelos com reproduções em gesso, papelão e papel de acidentes geográficos e principais feitos históricos, etnográficos e industriais da Argentina, além de quadros e maquetes. Propostas que originaram instituições como o Museo Pedagógico de la Provincia de Buenos Aires, o Museo Popular-Escolar de Las Conchas e o Museo Escolar Sarmiento.

Outras aproximações entre o método escolhido para o ensino público no Rio Grande do Sul, sua aplicação e a lógica dos museus são percebidas nos relatórios de 1916 e 1917 . No primeiro, Protasio Alves cita a realização de exposições anuais, em Porto Alegre e nas sedes dos colégios complementares, com apresentação de trabalhos manuais feitos em sala de aula. No segundo, ele menciona "museus industriais", a serem montados pelas e nas escolas industriais e estações zootécnicas e de agricultura dependentes dos cursos de Medicina Veterinária e Agronomia (RIO GRANDE DO SUL, 1917, p. XIII). Estes últimos necessitam ser melhor investigados.

Até o fim da gestão Borges de Medeiros, Protasio Alves segue relatando a compra, fabricação e entrega constante de mobiliário e de material de ensino para as escolas públicas. Em seu balanço de 1927 ele afirma que:

Foi com regularidade e cuidadosamente fornecido o material escolar aos estabelecimentos públicos, não obstante verificou-se que a verba votada para esse fim foi deficiente. O material é distribuído em face de pedido para cada estabelecimento que o faz, tendo em vistas as sobras e a matrícula de alunos pobres. O considerável aumento do número de estabelecimentos de ensino e frequência dos que vêm funcionando de anos anteriores tem determinado necessidades de mobiliário acima da produção possível pelas oficinas da Casa de Correção, de sorte que se torna necessária a aquisição de móveis para o fornecimento. (RIO GRANDE DO SUL, 1927, p. XX).

No entanto, é seu sucessor, Osvaldo Aranha, quem apresenta ao novo presidente do Estado, Getúlio Vargas, um balanço da educação pública sob o ponto de vista ideológico do PRR, abrangendo desde a instituição da República até o último dia de Protasio Alves como secretário dos Negócios do Interior e Exterior:

Conseguimos assim, distribuir um ensino útil, fecundo, intuitivo e uma educação física, cívica, higiênica e social. Não ensinamos a ler, mas a saber, a viver e a trabalhar. Cada criança que esta escola integrar na vida social será um potencial de trabalho e de progresso imensamente reprodutivo, quer do ponto de vista econômico, quer do ponto de vista financeiro. (RIO GRANDE DO SUL, 1928, p. 33).

A partir das lições recebidas de Protasio Alves e em continuidade ao trabalho dos seus antecessores, Aranha sugere medidas para um plano sistemático de reformas e de ação, como a criação da Diretoria da Instrução Pública; a reforma do ensino complementar, com criação 
de novas escolas introdutórias e para formação de professores; o aumento da verba para o material escolar e a criação da Revista do Ensino, entre outras medidas.

Ricos em informações apresentadas em tabelas, mapas e gráficos, os Relatórios da Instrução Pública do Rio Grande do Sul oferecem indícios da cultura material escolar produzida e adquirida pelas instâncias governamentais em consonância com as prerrogativas do que se considerava uma moderna pedagogia. Chegar às práticas entre os sujeitos no âmbito do espaço escolar através da utilização desses artefatos é tarefa mais complexa para a história da educação. As imagens fotográficas, nesse sentido, podem oferecer algumas pistas nessa direção.

\section{A sala de aula como imagem do progresso}

As imagens fotográficas podem constituir-se em documentos ricos para apreender a cultura material da escola, sendo ela mesma produto da cultura visual escolar. Para tanto, este trabalho se baseia em Knauss (2006) quando ele aponta que:

Ao nos referirmos às instituições, interessa observar as relações sociais organizadas em torno da produção da imagem e sua circulação. Os corpos, por sua vez, lembram-nos a necessidade de considerarmos a presença do observador, do espectador, como um "outro" necessário nos circuitos da promoção do significado visual, e que alguém conduz o controle da imagem. O plano da figuração não permite esquecer que as imagens têm um papel privilegiado no sentido de representar ou figurar o mundo em formas visuais. [...] A dialética entre o ver e o não-ver interroga o conhecimento como fruto do sensível, defendendo a ponte entre o dado e a abstração que permite ver onde os outros não vêem. Trata-se de definir o olhar como pensamento e fazer dele matéria do conhecimento histórico. (KNAUSS, 2006, p. 114-115).

Os relatórios investigados possuem poucos registros fotográficos. A única série de fotografias ilustrativas da escola pública e de suas atividades corresponde ao volume relativo ao ano de 1924, cujas imagens estão apresentadas no formato foto/legenda e sem identificação do autor, provavelmente um profissional contratado para essa função. Nos relatórios, essas imagens têm o objetivo de documentar os avanços realizados pelo governo do PRR a partir da adoção de novidades e tendências identificadas com a "moderna pedagogia" pelos gestores da Instrução Pública. Nesse sentido, outras imagens provenientes de acervos museológicos e álbuns comemorativos foram agregados ao estudo.

Para a perspectiva apresentada neste trabalho, foram selecionadas quatro imagens fotográficas, duas de sala de aula e duas das oficinas de marcenaria e serralheria da Casa de Correção, escolhidas por seu propósito documental e ilustrativo e também pelo caráter representativo da interação de alunos, professores e produtores com os objetos de ensino e o mobiliário. O conceito "escola desejada" é usado aqui conforme proposto por Possamai, apresentando a ideia de uma "educação científica, racional e moderna, dentro do desejo republicano" (POSSAMAI, 2009, p. 940), cujas ideias recebem reforço por meio da representação fotográfica, feita de forma a construir a imagem de uma escola-monumento.

A primeira delas é de uma aula prática do Colégio Complementar de Porto Alegre, instituição definida como "escola modelo" por Protasio Alves já no início de sua gestão como secretário: 
As escolas complementares são excelentes estabelecimentos de instrução. A que foi localizada em Porto Alegre, dotada de casa própria e de outros melhoramentos, que espero em breve ver realizados, será verdadeira escola modelo. Estão já encomendados aparelhos apropriados para que tenha o mais completo cunho o ensino. $\mathrm{O}$ ilustrado diretor, logo que receber os mapas murais, iniciará pessoalmente o ensino de leitura às classes elementares pelo método clássico João de Deus, incomparável quando bem aplicado, o que até agora aqui não se tem feito. Essas lições serão assistidas pelos alunos do curso superior, que se destinam ao magistério e vão às aulas elementares aprender a técnica magistral. (RIO GRANDE DO SUL, 1907, p. 11).

$\mathrm{Na}$ imagem, estudantes em preparação para o magistério estão em frente a uma classe de crianças e observam a metodologia empregada para educá-las. Afora a legenda que acompanha a fotografia, não há mais informações sobre a atividade e o cotidiano que ela representa. Imagens como esta, na qual as normalistas se posicionam frente à classe não juntamente a ela, observando a professora, são incomuns, cabendo um estudo posterior mais apurado do que a fotografia abaixo representa para a formação de professores no período.

Em relação à materialidade escolar, se percebe, em primeiro lugar, o ambiente amplo e iluminado, além dos conjuntos de bancos e carteiras tipo Triumph e um sistema de lousas intercambiantes. As crianças, todas uniformizadas em branco, têm suas mesas vazias e se posicionam todas da mesma forma, com as mãos recolhidas no colo. As normalistas tomam nota, enquanto o foco está na atuação da professora da classe.

Figura 1 - “Colégio Complementar - Capital. Aula Prática." Sem assinatura.

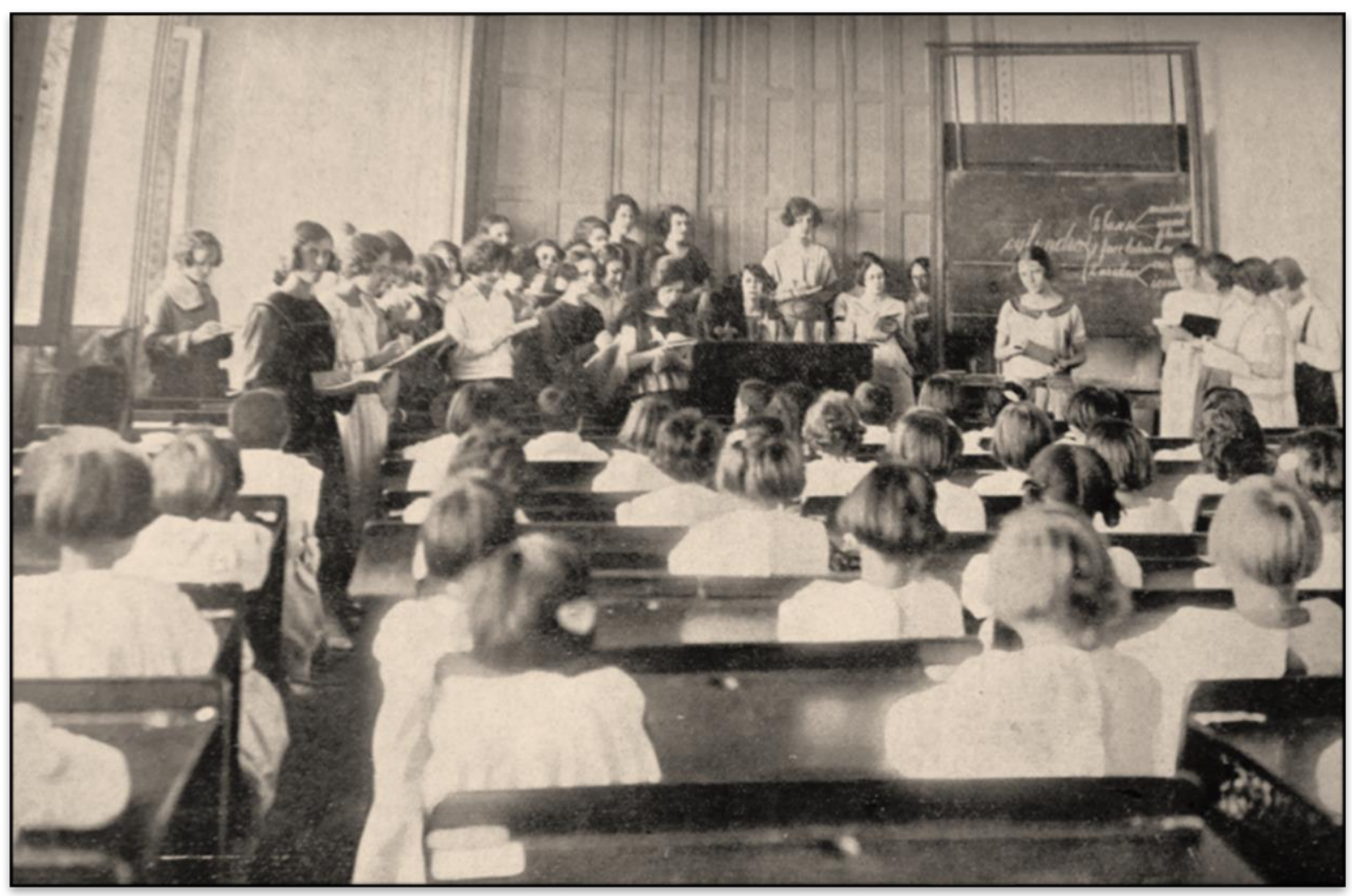

Fonte: RIO GRANDE DO SUL. Relatório apresentado ao Exmo. Sr. Dr. A. A. Borges de Medeiros, Presidente do Estado do Rio Grande do Sul, pelo Dr. Protasio Alves, Secretário de Estado dos Negócios do Interior e Exterior, em 6 de setembro de 1924. Porto Alegre: Officinas Graphicas d'A Federação, 1924. Acervo do Memorial do Legislativo do Rio Grande do Sul. 
A segunda imagem retrata uma aula de canto no Colégio Elementar do município de Cachoeira. Em termos da cultura material e visual representada, é a mais rica. Além dos bancos e carteiras, é possível visualizar uma parede com três níveis de prateleiras, preenchidas com quadros murais e com um ábaco, e um grande armário ao fundo da sala. Pode-se inferir que ele abriga uma das coleções escolares do Museu Julio de Castilhos, além de materiais como livros, sólidos geométricos e mapas. Um quadro mural em um suporte, provavelmente com uma canção, é apontado com uma régua por uma das professoras, enquanto a outra faz movimentos de regência. As crianças estão uniformizadas e sentadas com uma das mãos atrás das costas e a outra levantada, fazendo o mesmo gesto que a regente.

Figura 2 - "Colégio Elementar de Cachoeira - Grupo de alunos em aula de música.” Sem assinatura.

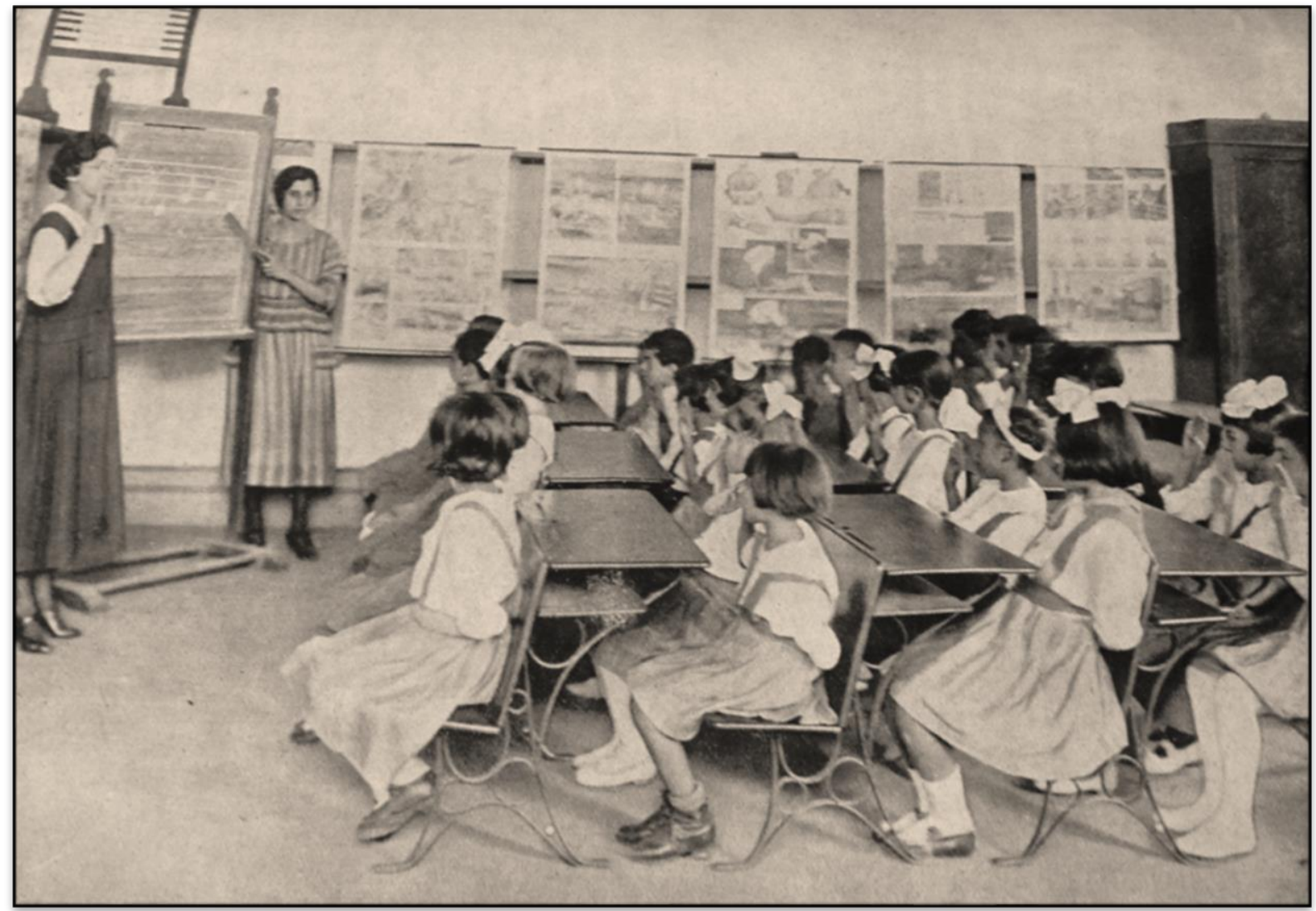

Fonte: RIO GRANDE DO SUL. Relatório apresentado ao Exmo. Sr. Dr. A. A. Borges de Medeiros, Presidente do Estado do Rio Grande do Sul, pelo Dr. Protásio Alves, Secretário de Estado dos Negócios do Interior e Exterior, em 6 de setembro de 1924. Porto Alegre: Officinas Graphicas d'A Federação, 1924. Acervo do Memorial do Legislativo do Rio Grande do Sul.

Essas imagens fotográficas diferem de outras, também inseridas nos relatórios governamentais produzidos no mesmo contexto republicano, com o objetivo de documentar ações e obras realizadas no ano que findara. Estudo anterior (POSSAMAI, 2009) aponta que predominavam quantitativamente nos relatórios da Instrução Pública do Rio Grande do Sul imagens das edificações escolares, pois estas tinham por objetivo especial dar a ver as obras de construção realizadas ou em andamento por parte do executivo estadual.

De modo diverso, as imagens escolares aqui apresentadas circunscrevem-se ao cenário do interior das salas de aula, no qual podem ser observados os aspectos espaciais e da cultura material e visual escolar do contexto, mas também os sujeitos em ação. A partir da análise 
dessas imagens, percebe-se que ambas foram produzidas com o propósito de mostrar e registrar a existência de ordem, regras, método e limpeza na Instrução Pública, ou seja, de criar a visibilidade de uma escola desejada no projeto político republicano. Isso é percebido pela uniformização das crianças, não apenas nas roupas e nos laços de cabelo das meninas, mas também em suas posições em pose. As professoras e normalistas, por meio de sua postura, participam da encenação, fingindo desinteresse pela câmera que documenta sua atividade. A exceção que denuncia a cena é o olhar de uma normalista na primeira imagem, que olha diretamente para o fotógrafo e acaba por captar o olhar do observador, como se desafiasse o pesquisador a decifrar o que se então se passava.

A terceira e quarta imagens estudadas representam a atividade dos apenados nas oficinas de marcenaria e de serralheria que fabricavam o mobiliário escolar. Nas imagens, as protagonistas são as oficinas, retratadas em plano aberto. Em ambas as imagens, chama atenção a imobilidade dos apenados que posam e não são fotografados em atividade, aspecto que demonstra o momento extraordinário da presença do fotógrafo no seu ambiente de trabalho. $\mathrm{O}$ uniforme homogeneíza esses trabalhadores e lhes inscreve uma identificação visual como apenados da Casa de Correção. Os ambientes possuem janelas e iluminação natural e a representação fotográfica passa, assim como no caso da sala de aula do Colégio Complementar, uma impressão de ordem, regras, método e higiene.

Figura 3 - "Marcenaria da Casa de Correção de Porto Alegre, 1913". No carimbo: "Casa de Correção, 25/1/1913, parte ilegível, Porto Alegre, Estado do Rio Grande do Sul”. Sem assinatura.

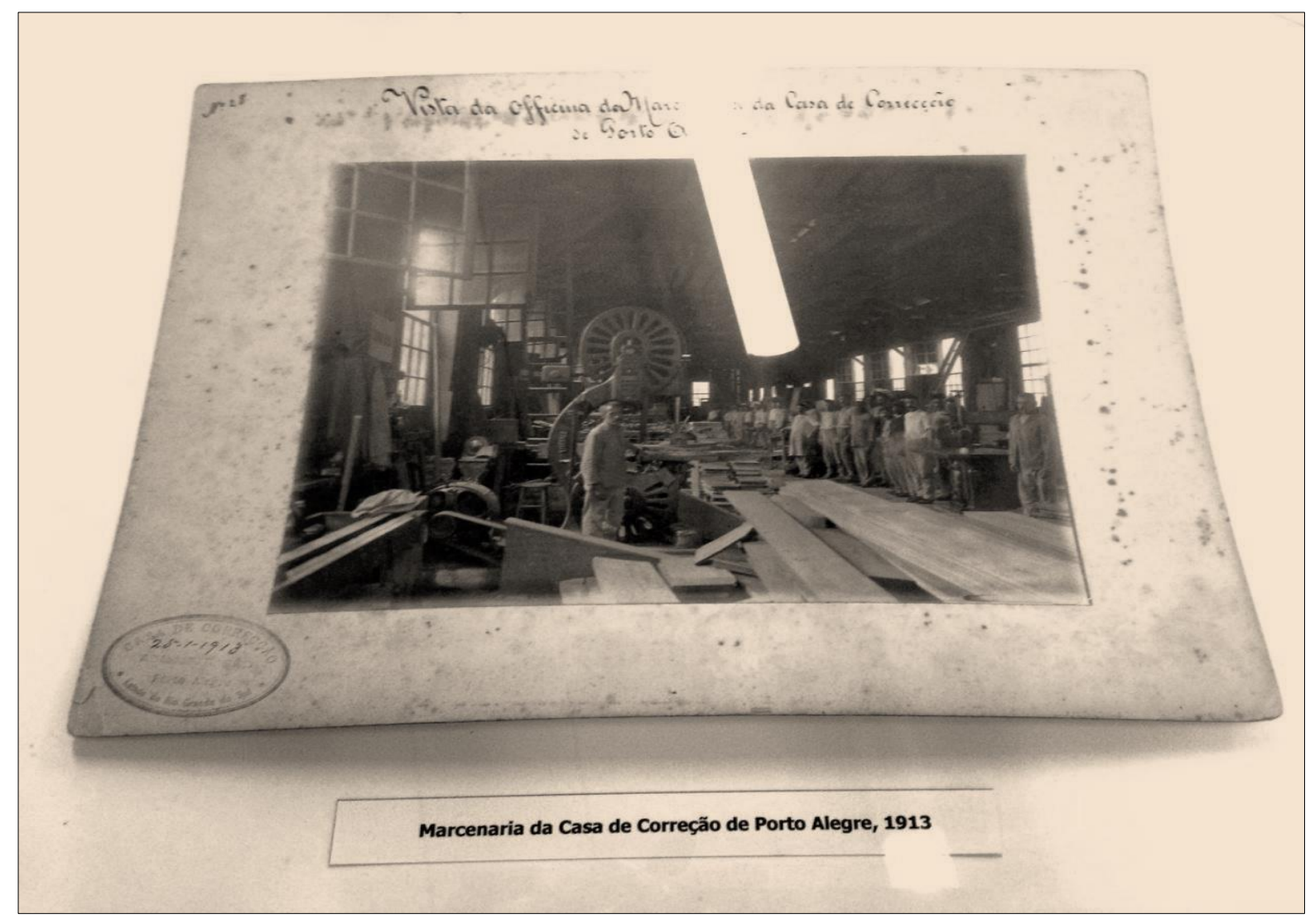

Fonte: Exposição “Casa de Correção - Dizer o Indizível”, Museu Julio de Castilhos, Porto Alegre, 2017. Acervo do Museu. Reprodução Cristiane Miglioranza. 
Figura 4 - Casa de Correção (título original). Oficinas de Serralheria (legenda original).

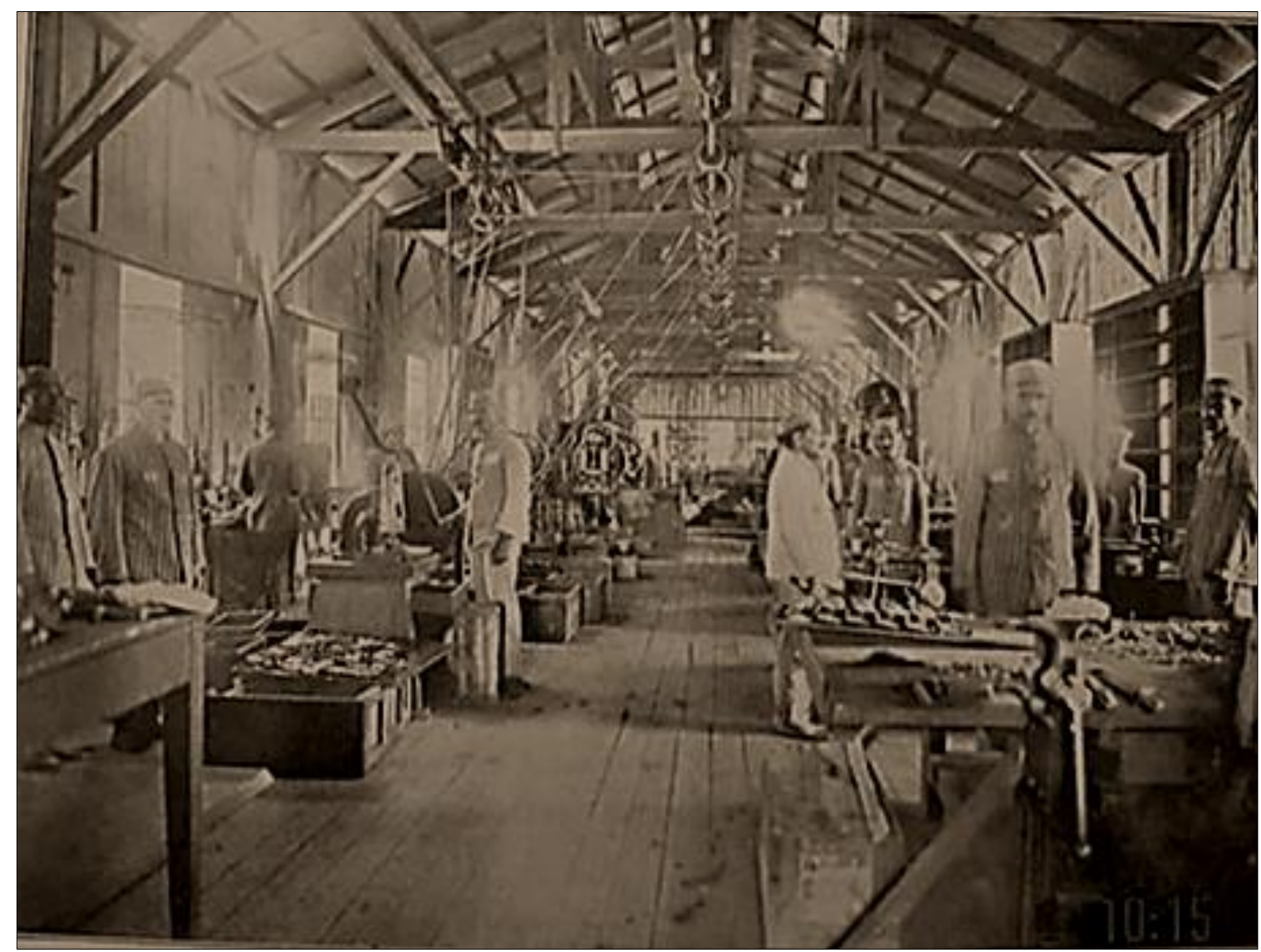

Fonte: ESTADO DO RIO GRANDE DO SUL. [Secretaria de Obras Públicas]. Obras públicas: centenário da Indepenência. Porto Alegre: Officinas Graphicas d'A Federação, 1922. Acervo: AHRGS.

Essas imagens, entrelaçadas com as pistas escritas encontradas sobre a cultura material escolar, permitem alcançar elementos da cultura escolar, mas também das relações sociais daquele contexto histórico que vão muito além do universo da escola. Inicialmente, os aspectos de produção das carteiras escolares, enunciados como fabricados pela Casa de Correção, deram pouca ou nenhuma visibilidade aos sujeitos que efetivamente confeccionaram esses artefatos. As imagens, embora circunscritas às configurações de um olhar fotográfico, permitiram dar visibilidade a esses sujeitos. De algum modo, alunos e alunas, professoras e normalistas a partir da escola estiveram ligados aos apenados da Casa de Correção, que fabricaram as carteiras das salas de aula.

\section{Considerações finais}

A nova ordem republicana no Rio Grande do Sul foi marcada na Instrução Pública por um governo centralizado de características positivistas. Foi preocupação dos ocupantes desta pasta, adequar as escolas a uma "moderna pedagogia", em cujo cerne encontrou-se a adoção do método intuitivo como novidade no ensino. Para concretizar a tão almejada modernização, era imprescindível a aquisição de artefatos, livros, mapas murais e mobiliário adequados aos preceitos pedagógicos e de saúde, amplamente difundidos em outros países. 
As necessidades de materiais por parte dos professores requereram a organização de uma logística com vistas ao levantamento das demandas, compra por parte do governo junto às empresas fabricantes e, posterior, distribuição às escolas de todo o território gaúcho. Um exemplo dessa prática foi a compra e a distribuição de três mil carteiras Triumph, da American Seating Company, entre outros materiais didáticos.

Entretanto, nem sempre foi viável adquirir os materiais considerados mais avançados, pois a importação de empresas estrangeiras tornava os preços demasiadamente elevados para as possibilidades do estado. Para resolver essa situação, os agentes educacionais lançaram-se à prática de manufatura por conta própria e com os recursos disponíveis dos artefatos e mobiliários dos quais necessitavam. Assim, os presos da Casa de Correção passaram a fabricar as carteiras escolares no mesmo modelo adquirido mediante importação; o Museu Júlio de Castilhos confeccionou museus escolares com amostras de minerais para as escolas, entre outras iniciativas.

Desse modo, foram observadas circulações e transferências de artefatos da cultura material, bem como ideias e saberes que serviram de substrato aos agentes brasileiros no sentido de propor medidas locais para a implementação de uma escola desejada nos moldes da moderna pedagogia, tão propalada nos seus escritos. Embora justifiquem-se os preços elevados para a não aquisição de vários desses materiais, importa destacar as soluções criativas e as práticas peculiares que deram corpo a uma escola real, cujos vestígios e pistas foram aqui perseguidos.

As parcas imagens fotográficas presentes nos relatórios da Instrução Pública mostram de modo diverso a escola em relação a outras imagens que davam a ver exclusivamente os prédios escolares. Para registrar em imagem a cultura material e projetar as práticas a ela relacionadas, era imprescindível dar a ver o interior das salas de aula. Desse modo, as pesquisadoras puderam observar em imagem uma escola desejada e seus sujeitos, professoras e alunas, em ação na ordem e tranquilidade de uma aula, ao menos enquanto o fotógrafo estava presente para a feitura do registro extraordinário, a ser eternizado para as pesquisadoras do presente. Outras pistas foram buscadas para montar esse mosaico da história da cultura material e visual de outrora. Nesse sentido, as imagens fotográficas das oficinas da Casa de Correção, uma delas publicada num álbum comemorativo do Governo do Estado e outra encontrada numa exposição do Museu Júlio de Castilhos, auxiliaram a visualizar os produtores do mobiliário presente nas salas de aulas. Desse modo, foi possível imbricar uma cultura mais ampla daquele contexto histórico com a cultura material e visual da escola.

Em relação à Instrução Pública no Rio Grande do Sul e à cultura material e visual geradas pela atividade educativa local, ainda há muito a ser pesquisado, principalmente no que diz respeito às memórias sociais envolvidas, às representações e imaginários e às reminiscências materiais, que perduram mudas nos acervos dos museus, no aguardo de pesquisas e exposições, ou ainda invisíveis nas instituições escolares, à espera de um olhar que as valorize como patrimônio educativo.

\section{Referências}

ALVES, Claudia. Educação, memória e identidade: dimensões imateriais da cultura material escolar. História da Educação, Pelotas, n. 30, 101-125, jan./abr. 2010.

CESAR, Tiago da Silva. A ilusão panóptica: encarcerar e punir nas imperiais cadeias da Província de São Pedro (1850-1888). Dissertação (mestrado). Universidade do Vale do Rio dos Sinos, Programa de Pós-Graduação em História, 2014. 226 p.: il. Disponível em http://biblioteca.asav.org.br/vinculos/000010/0000103f.pdf. Acesso em 04/06/2017. 
CORSETTI, Berenice. Controle e Ufanismo - A Escola Pública no Rio Grande do Sul (1889/1930). História da Educação. Pelotas, n. 4, 57-75, set. 1998.

COSTA, David Antonio da. Análise da Primeira Arithmetica para Meninos de José Theodoro de Souza Lobo. Conferência Interamericana de Educação Matemática, 13a , 26 a 30 de junho de 2011, Recife (PE). Anais... Recife: Programa de Pós-graduação em Educação Matemática e Tecnológica Universidade Federal de Pernambuco, 2011, 1 CD ROM.

DITTRICH, Klaus. As exposições mundiais como meios para a circulação transnacional de conhecimentos sobre o ensino primário durante a segunda metade do século. História da Educação, Porto Alegre, v. 17, n. 41, set.-dez., 2013, p. 213-234. https://doi.org/10.1590/S2236-34592013000300013

Editor, O. (1938). Professor Manoel Pacheco Prates. Revista Da Faculdade De Direito, Universidade De São Paulo, 34(3), 29-31.

ESCOLANO BENITO, Augustín. La cultura material de la escuela y la educación patrimonial. Educatio Siglo XXI, Vol. 28 nº 2, 2010, p. 43-64.

FELGUEIRAS, Margarida Louro. Materialidade da cultura escolar: A importância da museologia na conservação/comunicação da herança educativa. Proposições, v.16, 1 (46), p. 87-102, jan/abr 2005.

FIGUEIREDO, Aldrin Moura de. A memória modernista do tempo do Rei: narrativa das guerras napoleônicas e do Grão-Pará nos tempos do Brasil Reino (1808-1831). Revista do Arquivo Geral da Cidade do Rio de Janeiro. Rio de Janeiro: Garamond, 2008. p. 25-41.

GARCÍA, Susana V. Lecciones “Objetivadas" Y Museos Escolares en la Argentina del Centenario. Museologia \& Interdisciplinaridade, Vol. III, nº5, maio/junho de 2014. p. 7593. https://doi.org/10.26512/museologia.v3i5.15471

JULIA, Dominique. A Cultura Escolar como Objeto Histórico. Revista Brasileira de História da Educação, v.1, n.1 [1], p. 9- 43, jan/jun 2001.

KNAUSS, Paulo. O desafio de fazer História com imagens: arte e cultura visual. ArtCultura, Uberlândia, v. 8, n. 12, jan.-jun. 2006, p. 97-115.

MATASCI, Damiano. A França, a escola republicana e o exterior: perspectivas para uma história internacional da educação no século 19. História da Educação, Porto Alegre, v. 20, n. 50, set.-dez. 2016, p. 139-155. https://doi.org/10.1590/2236-3459/66203

MEDINA, Camila Beltrão. Lições de coisas e sua transposição para livros de leitura brasileiros (1907-1945): a história da educação pela clivagem do impresso. Tese (Doutorado em Educação). Universidade de São Paulo. 2012. 251 p.

MENDOZA, Vandari M. La vida en el aula de los artefactos pedagógicos. Inventos para la enseñanza objetiva en México, 1876-1910. In: DÁVILA, Paulí; NAYA, Luis María (org.). Espacios y patrimonio histórico-educativo. Espanha: Erein, 2016. p. 499-511. 
MENESES, Ulpiano Bezerra de et al. Como explorar um museu histórico. São Paulo: Museu Paulista, 1992.

MENESES, Ulpiano T. Bezerra de. Rumo a uma "história visual". In: MARTINS, José de Souza, ECKERT, Cornélia \& NOVAES, Sylvia Caiuby (orgs.). O imaginário e o poético nas ciências sociais. Bauru: EDUSC, 2005. Cap. 2.

MIGLIORANZA, C. I. V.; POSSAMAI, Z. R. "De acordo com a moderna pedagogia": as lições, as coisas e a materialidade na instrução pública gaúcha (1891-1928). Seminário Nacional História e Patrimônio Cultural, 3 a 7 de outubro 2016, Porto Alegre (RS). Anais... Porto Alegre: Universidade Federal do Rio Grande do Sul, 2016. P. 714-730.

PATEL, Kiran Klaus. An Emperor without Clothes? The Debate about Transnational History Twenty-five Years On. Histoire@Politique, n. 26, mai-août 2015.

PETRY, Marilia Gabriela; SILVA, Vera Lucia Gaspar da. Museu escolar: sentidos, propostas e projetos para a escola primária (séculos 19 e 20). História da Educação, Porto Alegre, v. 17 n. 41, Set./dez. 2013, p. 79-101. ISSN 1414-3518. https://doi.org/10.1590/S2236$\underline{34592013000300006}$

POSSAMAI, Zita Rosane. Uma escola a ser vista: apontamentos sobre imagens fotográficas de Porto Alegre nas primeiras décadas do século XX. História da Educação, Pelotas, v. 13, n. 29, Set/Dez 2009, p. 143-169.

POSSAMAI, Zita Rosane. A grafia dos corpos no espaço urbano: os escolares no álbum Biografia duma Cidade, Porto Alegre, 1940. História da Educação (Online), Porto Alegre, v. 19 n.47 Set./dez. 2015, p. 129-148. https://doi.org/10.1590/2236-3459/46286

POSSAMAI, Zita Rosane. Colecionar e educar: o Museu Julio de Castilhos e seus públicos (1903-1925). Varia História (UFMG. Impresso), v. 30, p. 365-389, 2014. https://doi.org/10.1590/S0104-87752014000200003

POSSAMAI, Zita Rosane. "Lição de Coisas" no Museu: o Método Intuitivo e o Museu do Estado do Rio Grande do Sul, Brasil, nas primeiras décadas do século XX. Arquivos Analíticos de

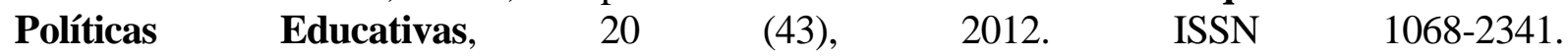
https://doi.org/10.14507/epaa.v20n43.2012

RAZZINI, Marcia de Paula Gregório. A Livraria Francisco Alves e a expansão da escola pública em São Paulo. SEMINÁRIO BRASILEIRO SOBRE O LIVRO E HISTÓRIA EDITORIAL, 1, 2004, Rio de Janeiro. Anais... Rio de Janeiro: Casa de Rui Barbosa, 2004. Traz também histórico da implantação da educação pública em SP e do uso de lições de coisas.

RIO GRANDE DO SUL. Decreto no 89, de 2 de Fevereiro de 1897. In: Leis, atos e decretos do Governo do Estado do Rio Grande do Sul. 1897. Porto Alegre: Officinas Typographicas de Echenique, 1897. p. 162-201.

RIO GRANDE DO SUL. Decreto $\mathbf{n}^{\circ}$ 874, de 28 de Fevereiro de 1906. In: Leis, decretos e actos do Governo do Estado do Rio Grande do Sul, 1906. Porto Alegre: Officinas Typographicas O Independente, 1912. p. 83-137. 
RIO GRANDE DO SUL. Decreto no 1746, de 25 de julho de 1911. Porto Alegre, 1911.

RIO GRANDE DO SUL. Secretaria de Obras Públicas. Obras públicas: centenário da Indepenência. Porto Alegre: Officinas Graphicas d'A Federação, 1922.

RIO GRANDE DO SUL. Relatório apresentado ao Presidente do Rio Grande do Sul em 15 de setembro de 1893 pelo Secretário de Estado interino dos Negócios do Interior e Exterior, Possidonio M. da Cunha Junior. Porto Alegre: Officinas Typographicas d'A Federação, 1893. Acervo do Memorial do Legislativo do Rio Grande do Sul.

RIO GRANDE DO SUL. Relatório apresentado ao Sr. Dr. Julio Prates de Castilhos, Presidente do Rio Grande do Sul, pelo Dr. João Abbot, Secretário de Estado dos Negócios do Interior e Exterior, em 31 de Julho de 1896. Porto Alegre: Officinas a Vapor da Livraria Americana, 1896. Acervo do Memorial do Legislativo do Rio Grande do Sul.

RIO GRANDE DO SUL. Relatório apresentado ao Sr. Dr. Julio Prates de Castilhos, Presidente do Estado do Rio Grande do Sul, pelo Dr. João Abbot, Secretário de Estado dos Negócios do Interior e Exterior, em 30 de Julho de 1897. Porto Alegre: Officinas a Vapor da Livraria Americana, 1897. Acervo do Memorial do Legislativo do Rio Grande do Sul.

RIO GRANDE DO SUL. Relatório apresentado ao Sr. Antonio Augusto Borges de Medeiros, Presidente do Estado do Rio Grande do Sul, pelo Dr. João Abbot, Secretário de Estado dos Negócios do Interior e Exterior, em 30 de Julho de 1898. Porto Alegre: Officinas Typographicas da Livraria do Globo, 1898. Acervo do Memorial do Legislativo do Rio Grande do Sul.

RIO GRANDE DO SUL. Relatório apresentado ao Sr. Dr. Antonio Augusto Borges de Medeiros, Presidente do Estado do Rio Grande do Sul, pelo Dr. João Abbot, Secretário de Estado dos Negócios do Interior e Exterior, em 30 de Julho de 1899. Porto Alegre: Officinas Typographicas de Emilio Wiedemann \& Filhos, 1899. Acervo do Memorial do Legislativo do Rio Grande do Sul.

RIO GRANDE DO SUL. Relatório apresentado ao Sr. Dr. Antonio Augusto Borges de Medeiros, Presidente do Estado do Rio Grande do Sul, pelo Dr. João Abbot, Secretário de Estado dos Negócios do Interior e Exterior, em 30 de Agosto de 1900. Porto Alegre: Officinas Typographicas da Livraria Americana, 1900. Acervo do Memorial do Legislativo do Rio Grande do Sul.

RIO GRANDE DO SUL. Relatório apresentado ao Sr. Dr. Antonio Augusto Borges de Medeiros, Presidente do Estado do Rio Grande do Sul, pelo Dr. Protasio Antonio Alves, Secretário de Estado dos Negócios do Interior e Exterior, em 15 de setembro de 1906. Porto Alegre: Typographia Emilio Wiedemann \& Filhos, 1906. Acervo do Memorial do Legislativo do Rio Grande do Sul.

RIO GRANDE DO SUL. Relatório apresentado ao Sr. Dr. Antonio Augusto Borges de Medeiros, Presidente do Estado do Rio Grande do Sul, pelo Dr. Protasio Antonio Alves, Secretário de Estado dos Negócios do Interior e Exterior, em 15 de setembro de 1907. Porto Alegre: Typographia D’O Debate, 1907. Acervo do Memorial do Legislativo do Rio Grande do Sul. 
RIO GRANDE DO SUL. Relatório apresentado ao Sr. Dr. Carlos Barbosa Gonçalves, Presidente do Estado do Rio Grande do Sul, pelo Dr. Protasio Antonio Alves, Secretário de Estado dos Negócios do Interior e Exterior, em 8 de setembro de 1908. Porto Alegre: Officinas Graphicas da Livraria do Globo, 1908. Acervo do Memorial do Legislativo do Rio Grande do Sul.

RIO GRANDE DO SUL. Relatório apresentado ao Sr. Dr. Carlos Barbosa Gonçalves, Presidente do Estado do Rio Grande do Sul, pelo Dr. Protasio Antonio Alves, Secretário de Estado dos Negócios do Interior e Exterior, em 8 de setembro de 1909. Porto Alegre: Officina typographica da Livraria Universal de Carlos Echenique, 1909. Acervo do Memorial do Legislativo do Rio Grande do Sul.

RIO GRANDE DO SUL. Relatório apresentado ao Sr. Dr. Carlos Barbosa Gonçalves, Presidente do Estado do Rio Grande do Sul, pelo Dr. Protasio Antonio Alves, Secretário de Estado dos Negócios do Interior e Exterior, em 8 de setembro de 1910. Porto Alegre: Typrographia da Livraria Universal de Carlos Echenique, 1910. Acervo do Memorial do Legislativo do Rio Grande do Sul.

RIO GRANDE DO SUL. Relatório apresentado ao Exmo. Sr. Dr. Carlos Barbosa Gonçalves, Presidente do Estado do Rio Grande do Sul, pelo Dr. Protasio Antonio Alves, Secretário de Estado dos Negócios do Interior e Exterior, em 9 de setembro de 1912. Porto Alegre: Officinas Graphicas da Livraria do Globo, 1912. Acervo do Memorial do Legislativo do Rio Grande do Sul.

RIO GRANDE DO SUL. Relatório apresentado ao Exmo. Sr. Dr. A. A. Borges de Medeiros, Presidente do Estado do Rio Grande do Sul, pelo Dr. Protasio Antonio Alves, Secretário de Estado dos Negócios do Interior e Exterior, em 3 de setembro de 1913. Porto Alegre: Officinas Graphicas da Livraria do Globo, 1913. Acervo do Memorial do Legislativo do Rio Grande do Sul.

RIO GRANDE DO SUL. Relatório apresentado ao Exmo. Sr. General Salvador Ayres Pinheiro Machado, Vice-Presidente do Estado do Rio Grande do Sul, pelo Dr. Protasio Antônio Alves, Secretário de Estado dos Negócios do Interior e Exterior, em 8 de setembro de 1916. I Volume. Porto Alegre: Officinas Graphicas d'A Federação, 1916. 2 Vol. Acervo do Memorial do Legislativo do Rio Grande do Sul.

RIO GRANDE DO SUL. Relatório apresentado ao Exmo. Sr. Dr. A. A. Borges de Medeiros, Presidente do Estado do Rio Grande do Sul, pelo Dr. Protasio Antônio Alves, Secretário de Estado dos Negócios do Interior e Exterior, em 27 de agosto de 1917. I Volume. Porto Alegre: Officinas Graphicas d'A Federação, 1917. 2 Vol. Acervo do Memorial do Legislativo do Rio Grande do Sul.

RIO GRANDE DO SUL. Relatório apresentado ao Exmo. Sr. Dr. A. A. Borges de Medeiros, Presidente do Estado do Rio Grande do Sul, pelo Dr. Protasio Alves, Secretário de Estado dos Negócios do Interior e Exterior, em 6 de setembro de 1924. Porto Alegre: Officinas Graphicas d'A Federação, 1924. Acervo do Memorial do Legislativo do Rio Grande do Sul.

RIO GRANDE DO SUL. Relatório apresentado ao Exmo. Sr. Dr. A. A. Borges de Medeiros, Presidente do Estado do Rio Grande do Sul, pelo Dr. Protasio Antonio Alves, Secretário de Estado dos Negócios do Interior e Exterior, em 24 de agosto de 1927. Porto Alegre: Officinas Graphicas d'A Federação, 1927. Acervo do Memorial do Legislativo do Rio Grande do Sul. 
RIO GRANDE DO SUL. Relatório apresentado ao Dr. Getúlio Vargas, Presidente do Estado do Rio Grande do Sul, pelo Dr. Oswaldo Aranha, Secretário de Estado dos Negócios do Interior e Exterior, em 25 de agosto de 1928. I Volume. Porto Alegre: Officinas Graphicas d'A Federação, 1928. Acervo do Memorial do Legislativo do Rio Grande do Sul.

SÃO PAUlO. Lei n. $\mathbf{8 8}$, de $\mathbf{8}$ de setembro de $\mathbf{1 8 9 2}$. Disponível em http://www.al.sp.gov.br/norma/?id=64173. Acesso em 11/12/2015.

SOUZA, Rosa Fátima de. História da Cultura Material escolar: um balanço inicial. In: BENCOSTA, Marcus Levy Albino. (Org.). Culturas escolares, saberes e práticas educativas: itinerários históricos. São Paulo: Cortez, 2007. P. 163-189.

SZCZEPANIAK, Ivone. Poder imposto: negociações que fogem às regras - o que podemos localizar nas fontes. Simpósio Nacional de História da ANPUH, XXIII, 17 a 22 de maio de 2005, Londrina (PR). Anais... Londrina: Editorial Mídia, 2005. Disponível em http://anais.anpuh.org/wpcontent/uploads/mp/pdf/ANPUH.S23.0472.pdf. Acesso em 04/06/2017.

TAMBARA, E. A. C.; ARRIADA, Eduardo. A cultura escolar material, a modernidade e a aquisição da escrita no Brasil no século XIX. Educação, Porto Alegre, v. 35, n. 1, p. 73-88, jan./abr. 2012.

VALDEMARIN, V. T. Estudando as Lições de Coisas: análise dos fundamentos filosóficos do método de ensino intuitivo. Campinas: Autores Associados, 2004.

VIDAL, Diana. Cultura e prática escolares: uma reflexão sobre documentos e arquivos escolares. In: SOUZA, Rosa Fátima de; VALDEMARIN, Vera Teresa (Orgs.). A cultura escolar em debate: questões conceituais, metodológicas e desafios para a pesquisa. Campinas: Autores Associados, 2005. P. 3-30.

VIÑAO, Antonio. Memoria, patrimonio y educación. Educatio Siglo XXI, Vol. $28 \mathrm{n}^{\mathrm{o}} 2$ • 2010, pp. 17-42.

VIOLA, Solon. As propostas educativas das escolas públicas no início do século. In: GRAEBIN, Cleusa Maria Gomes. Revisitando o Positivismo. Canoas: La Salle, 1998. p. 183-196. 